\title{
Effects of dietary vitamin C supplementation on fatty acid profile in breast meat of broiler chickens
}

\author{
Masoomeh Tavakoli ${ }^{1}$, Mehrdad Bouyeh ${ }^{1 \star}$, Alireza Seidavi ${ }^{1}$
}

\begin{abstract}
This experiment was performed to evaluate the effects of using three different levels of vitamin $C$ $(0,200$ and $400 \mathrm{mg} / \mathrm{kg})$ in diet on fatty acid profiles of breast meat of broilers. The experiment was performed in a completely randomized design in 3 treatments and 4 replicates with 10 chickens per pen for 42 days using 120 one-day-old male chickens of commercial Ross 308 strain. Data analysis was performed by SAS statistical software and the comparison of the means with Duncan's multiple-range test at 5\% probability level. The results showed that the percentage of saturated fatty acids such as myristic acid, palmitic acid and stearic acid decreased by $200 \mathrm{mg} / \mathrm{kg}$ vitamin C. Also, the amount of unsaturated fatty acids increased at the same level of vitamin $C$ and the saturated fatty acids were reduced.
\end{abstract}

Key words: chick, ascorbic acid, fatty acid profile.

\section{Introduction}

Numerous studies have shown that vitamin $C$ as a nutrient can improve poultry performance. This vitamin is soluble in water and its main function is its antioxidant properties. It can also destroy high levels of free radicals produced in cells RUSSEL \& MC DOWELL (1989). The use of vitamin C in conditions of environmental, nutritional, and genetic stresses has been extensively studied, and the results indicate improved performance due to its use (COATES 1984; HORNIG et al., 1984). But the use of this vitamin and its role fatty acid profile in breast meat of broiler chickens has always been less considered. In fact, vitamin C prevents stress by preventing the release of corticosteroid hormones, which in turn can be effective in poultry perfor- mance, production, and reduction of losses RUSSEL \& MC DOWELL (1989). In addition, local oxidative damages alter the structure of proteins, which can manifest in the activity of pancreatic enzymes and prevent their proper activity. Therefore, the presence of an antioxidant such as vitamin $C$ can prevent the abnormalization of proteins, which is also true of the hormone insulin, thereby improving the biological activity of this hormone and the effect of oxidation, digestion of nutrients and thus increasing the efficiency result (CIFTCI, 2005).

According to the contradictory results on the antioxidant effect of vitamin $C$ on the mentioned factors and the insufficiency of previous articles in this field and the lack of comprehensive

${ }^{1}$ Masoomeh Tavakoli, Mehrdad Bouyeh, Alireza Seidavi; Department of Animal Science, Rasht Branch, Islamic Azad University, Rasht, Iran *Corresponding author: booyeh@iaurasht.ac.ir 
research to control all the parameters related to production that were studied together in this study, and according to the limited results regarding the use of this vitamin in normal breeding conditions, the present study was performed to investigate different doses of vitamin C on fatty acid profiles in breast meat of broilers.

\section{Materials and Methods}

The study was conducted at a broiler farm in Masal, Iran. The experiment was performed with 120 one-day-old male chickens of commercial Ross 308 strain with an average weight of $45 \pm 2 \mathrm{~g}$, in a completely randomized design with 3 treatments and 4 replicates and 10 chickens per pen for 42 days. The studied treatments were treatment 1 (VCO mg/ $\mathrm{kg})$, treatment 2 (VC200 mg/kg) and treatment 3 (VC400 mg/kg) which were used in combination with the basal diet. Vitamin $C$ was used based on the desired concentrations. The diets were grinded and adjusted according to the table of nutritional needs of poultry feed containing the minimum recommended nutrients in the Ross 308 feed guide (MANUAL, 2012) (Table 1). The chickens were raised in $1 \times 1 \mathrm{~m}$ cages on a bed of cellulose roll for 42 days. Each cage contained a cylindrical feeding container and a manual chicken drinker. The temperature in the breeding hall was $33^{\circ} \mathrm{C}$ in the first week and then gradually dropped to $23^{\circ} \mathrm{C}$ on the 18 th day of breeding and then continued until the end of the period with the same temperature. Environmental conditions were similar for all chicks and included 23 hours of exposure and one hour of darkness, with room humidity of 65 to $70 \%$. Access to water and feed during the breeding period was similar and free. In addition, the birds were vaccinated against infectious bronchitis (10th day of age), Newcastle disease (4th, 21st and 35th days of age) and infectious Bursal disease (12nd day of age). All the vaccines were obtained from the Razi Vaccine and Serum Institute (Karaj, Iran). Other rearing methods was followed based on (GOLROKH et al., 2016).

In order to measure the profile of fatty acids in 42 days 1 bird from each treatment was slaughtered and the sample of breast meat was transferred to the laboratory. To do this, the muscle breast was first isolated, then grinded and kept in a freezer at $-20^{\circ} \mathrm{C}$ (to protect the tissue and compound of the flesh). The fat content of the samples was extracted by the method of (FOLCH et al., 1957). First a mixture of two strong solvents of chloroform and methanol was prepared with the ratio of 2 to 1 , respectively. The amount of one gram of the mixed samples was then weighed and poured into the closed test tubes. Then $15 \mathrm{cc}$ of the prepared solvent was added to it and thoroughly mixed and then kept in the refrigerator for 24 hours. After the mentioned duration, 5 cc of distilled water was added to the samples to create 3 phases in the test tube. After separating the bottom phase, which contains chloroform and dissolved fat, this part was poured into special centrifugal tubes and centrifuged at $25^{\circ} \mathrm{C}$ with $3000 \mathrm{rpm}$ for 15 minutes until the phases of chloroform and fat were completely separated. This process was performed twice, and at the end, after final centrifugation, the bottom phase, which contained only chloroform and dissolved fat, was separated and poured into a clean laboratory container. After the solution was poured into the test tube, the tube was placed under the laboratory hood in $70^{\circ} \mathrm{C}$ water and nitrogen gas was blown on it to evaporate the chloroform. Then, $50 \mathrm{mg}$ of pure extracted fat was removed and it was affected by base and acid methylation in two stages. First, the fat sample was located 30 minutes under the influence of $0.5 \mathrm{M}$ methoxide solution in methanol at $50^{\circ} \mathrm{C}$ and then under the influence of chloridric acid solution in methanol (1:1 ratio) for 30 minutes at $50^{\circ} \mathrm{C}$. The methyl ester of fatty acids produced in hexane was dissolved by adding hexane to the solution. Then, by adding dry sodium sulfate to the solution and final dehydration, methyl esters of fatty acids dissolved in hexane were passed through a special filter and prepared for injection into the column of chromatographic gas device (Agilent America, 7890B GC Series). Cl3 fatty acids were used as the standard. Pure nitrogen was used as the carrier gas for injection into the chromatographic gas device in a ratio of 1 to 50 . The temperature schedule used for the column was such that the temperature of the oven was kept constant for 4 minutes at $100^{\circ} \mathrm{C}$. Then, it reached a temperature of $240^{\circ} \mathrm{C}$ at a rate of $3^{\circ} \mathrm{C}$ per minute, and was then kept at a constant temperature of $240^{\circ} \mathrm{C}$ for $20 \mathrm{~min}$. The temperature of injector was $225^{\circ} \mathrm{C}$ and the detector temperature was $250^{\circ} \mathrm{C}$. The analysis time of each sample was 71 minutes and it should be noted that the nitrogen gas pressure inside the column was 2.2 , the hydrogen gas pressure was 0.5 and the air pressure was $0.4 \mathrm{~kg} / \mathrm{m}^{3}$. 
Table 1 Ingredients, chemical composition, and energy of the used diets (from 1st to 42nd days of age)

\begin{tabular}{|c|c|c|c|}
\hline Ingredients (g/kg as-fed) & $\begin{array}{c}\text { Starter diet } \\
\text { (1st-10th days of age) }\end{array}$ & $\begin{array}{c}\text { Grower diet } \\
\text { (11st-24th days of age) }\end{array}$ & $\begin{array}{c}\text { Finisher diet } \\
\text { (25th-42nd days of }\end{array}$ \\
\hline Corn & 47.03 & 59.60 & 65.99 \\
\hline Wheat & 5.58 & 5.00 & 5.00 \\
\hline Soybean meal (44\% Crude protein) & 29.02 & 16.15 & 10.28 \\
\hline Corn gluten & 10.00 & 11.48 & 11.50 \\
\hline soy oil & 3.50 & 3.40 & 3.09 \\
\hline Limestone & 1.45 & 1.23 & 1.00 \\
\hline Di-calcium phosphate & 1.95 & 1.80 & 1.83 \\
\hline Salt & 0.20 & 0.20 & 0.20 \\
\hline Vitamin and mineral supplements ${ }^{1}$ & 0.50 & 0.50 & 0.50 \\
\hline DL-methionine & 0.52 & 0.58 & 0.57 \\
\hline L-lysine hydrochloride & 0.25 & 0.06 & 0.04 \\
\hline \multicolumn{4}{|l|}{ Calculated compounds } \\
\hline Metabolizable energy (kcal / kg) & 2950 & 3000 & 3050 \\
\hline Crude protein(\%) & 22 & 20 & 19 \\
\hline Lysine(\%) & 1.3 & 1.2 & 1.1 \\
\hline Methionine(\%) & 0.56 & 0.54 & 0.52 \\
\hline Met+Cys(\%) & 0.92 & 0.90 & 0.88 \\
\hline Calcium(\%) & 1.04 & 0.95 & 0.92 \\
\hline Available phosphorus & 0.52 & 0.47 & 0.41 \\
\hline
\end{tabular}

1. The amount of vitamins and minerals per kg of the final diet: vitamin A, 9000 IU; vitamin D3, 3000 IU; vitamin E, 18 IU; vitamin K3, 3 mg; vitamin B1(Thiamine), $1.8 \mathrm{mg} ;$ vitamin B2 (Riboflavin), $6 \mathrm{mg}$; vitamin B6 (Pyridoxine), $3 \mathrm{mg}$; vitamin B12 (Cyanocobalamin), $0.012 \mathrm{mg} ;$ vitamin B3 (Niacin), 30 mg; vitamin B9 (Folic acid), 1 mg; vitamin H3 (Biotin), 0.24mg; vitamin B5 (Pantothenic acid), 10 mg; 500 mg; Choline,100 mg; Mn,100 mg; Zinc, $80 \mathrm{mg}$; Iron, $10 \mathrm{mg}$; $\mathrm{Cu}, 1 \mathrm{mg}$; l, $0.2 \mathrm{mg}$. .

Table 2 Profile of breast fatty acids Ross 308 broilers at 42nd day of age fed diets containing different amounts of vitamin C

\begin{tabular}{|c|c|c|c|c|c|c|c|c|c|c|}
\hline $\begin{array}{c}\text { Vitamin } \\
\text { C } \\
(\mathrm{mg} / \mathrm{kg})\end{array}$ & $\begin{array}{l}\text { Myristic } \\
\text { Acid } \\
\text { Methyl } \\
\text { Ester } \\
\text { C14:0 } \\
\text { (\%) }\end{array}$ & $\begin{array}{l}\text { Palmitic } \\
\text { Acid } \\
\text { Methyl } \\
\text { Ester } \\
\text { C16:0 } \\
(\%)\end{array}$ & $\begin{array}{l}\text { Palmi- } \\
\text { toleic } \\
\text { Acid } \\
\text { Methyl } \\
\text { Ester } \\
\text { C16:1c } \\
(\%)\end{array}$ & $\begin{array}{l}\text { Stearic } \\
\text { Acid } \\
\text { Methyl } \\
\text { Ester } \\
\text { C18:0 } \\
\text { (\%) }\end{array}$ & $\begin{array}{l}\text { Oleic Acid } \\
\text { Methyl } \\
\text { Ester } \\
\text { C18:1n9c } \\
\text { (\%) }\end{array}$ & $\begin{array}{l}\text { Linoleic } \\
\text { Acid } \\
\text { Methyl } \\
\text { Ester } \\
\text { C18:2n6c } \\
(\%)\end{array}$ & $\begin{array}{l}\text { Linole- } \\
\text { nic Acid } \\
\text { Methyl } \\
\text { Ester } \\
\text { C18:3n3 } \\
(\%)\end{array}$ & $\begin{array}{c}\text { cis- } \\
\text { 11,14- } \\
\text { Eicosa- } \\
\text { dienoic } \\
\text { Acid } \\
\text { Methyl } \\
\text { Ester } \\
\text { C20:2c } \\
(\%)\end{array}$ & $\begin{array}{l}\text { cis-8,11,14- } \\
\text { Eicosa- } \\
\text { trienoic } \\
\text { AcidMethyl } \\
\text { Ester } \\
\text { C20:3n6c } \\
(\%)\end{array}$ & $\begin{array}{c}\text { cis- } \\
\text { 11,14,17- } \\
\text { Eicosatrie- } \\
\text { noic Acid } \\
\text { Methyl } \\
\text { Ester } \\
\text { C20:3 } \\
(\%)\end{array}$ \\
\hline 0 & 2.02 & 37.48 & 3.14 & 11.40 & 22.57 & 17.65 & 0.50 & 0.38 & 0.67 & 4.18 \\
\hline 200 & 0.61 & 35.17 & 2.92 & 9.40 & 23.69 & 21.91 & 0.54 & 0.62 & 0.55 & 4.59 \\
\hline 400 & 1.85 & 36.04 & 4.15 & 10.11 & 28.76 & 14.28 & 0.68 & 0.29 & 0.84 & 3.0 \\
\hline
\end{tabular}

\section{Results and Discussion}

The percentage of fatty acids in breast muscle tissue is shown in Table 2 . The results showed that the percentage of saturated fatty acids such as myristic acid, palmitic acid and stearic acid decreased by VC 200. This reduction is of great importance in terms of the role of saturated fatty acids in endangering human health. Therefore, the results of the present study can be useful. On the other hand, the use of the same level of vitamin C led to an increase in the level of beneficial unsaturated fatty acids such as linoleic acid, cis-11,14eicosadienoic acid and cis-11,14,17-eicosatrienoic 
acid. this is because the storage of $n-3$ polyunsaturated fatty acids in the breast muscle is greater than in the thigh muscle. These fatty acids are as a standard for biological studies. They are mainly found in small amounts in animal tissues (WANG et al, 2012 ; HUANG et al., 2011); cis -11,14- eicosadienoic acid is produced by an enzyme delta- 9 elongase from Linoleic acid and can be converted to dihomo- $\gamma$-linolenic acid, arachidonic acid, sciadonic acid and other unsaturated fatty acids. Cis -11,14eicosadienoic acid is able to regulate the metabolism of unsaturated fatty acids and is responsible for macrophage response to inflammatory stimulations. Together with other monounsaturated fatty acids, cis -11,14- eicosadienoic acid can inhibit the binding of leukotriene B4 to the neutrophil membrane, which is part of these anti-inflammatory activities (HUANG et al., 2011). In fact, vitamin $\mathrm{C}$ acts as an antioxidant in the body, which creates a compound (dehydroascorbic acid) through rapid oxidation and this compound protects cell membranes and unsaturated fatty acids of the membrane against the oxidation of Free radicals ZAHRAA and\& GHAMDI(2008).

\section{Conclusion}

Low levels of vitamin $\mathrm{C}$ have been linked to an increase in unsaturated fatty acids and a decrease in saturated fatty acids, which have been known to be beneficial to human health. Therefore, according to the results of this experiment, it is recommended to use $200 \mathrm{mg} / \mathrm{kg}$ vitamin C in diet as an antioxidant compound and a cheap promoter of meat.

\section{Acknowledgments}

This manuscript is prepared based on $\mathrm{PhD}$ thesis of first author at Rasht Branch, Islamic Azad University, Rasht, Iran. Financial support by Rasht Branch, Islamic Azad University, grant number 17.16.4.18418 is gratefully acknowledged.

\section{References}

[1] Ciftci, M., O. N. Ertas, T. Guler (2005): Effects of vitamin E and vitamin C dietary supplementation on egg production and egg quality of laying hens exposed to a chronic heat stress. Rev. Med. Vet, 156(2): 107-111.

[2] Coates, M., E. (1984): Metabolic Role of the Vitamins in Physiology and Biochemistry of the Domestic Fowl.27-36.

[3] Folch, J., M. Lees, G., S. Stanley (1957): A simple method for the isolation and purification of total lipides from animal tissues. Journal of biological chemistry, 226(1): 497-509.

[4] Golrokh, A., J. Bouyeh, M. Seidavi, A. Van Den Hoven, R., V. Laudadio, V. Tufarelli (2016): Effect of different dietary levels of atorvastatin and L-carnitine on performance, carcass characteristics and plasma constitutes of broiler chickens. The Journal of Poultry Science, 53(3): 201-207.

[5] Hornig, D., B. Glatthaar, U. Moser (1984): General aspects of ascorbic acid function and metabolism. In 1. International Workshop on Ascorbic Acid in Domestic Animals, Skjoldenaesholm (Denmark), Sep 1983. KDL.

[6] Huang, Y., S. Huang, W., C., W. Li, L., T. Chuang (2011): Eicosadienoic acid differentially modulates production of pro-inflammatory modulators in murine macrophages. Molecular and cellular biochemistry, 358(1-2): 85-94.

[7] Manual, R. B. (2012): Ross 308 broiler nutrition manual. Ross Broiler Ltd: Newbridge, Midlothian, UK.

[8] Russel, L., J. Mc Dowell (1989): Vitamins in animal nutrition. Academec Pres Inc., San Diego, California.

[9] Wang, X., H. Lin, Y. Gu (2012): Multiple roles of dihomo- $\gamma$-linolenic acid against proliferation diseases. Lipids in health and disease, 11(1): 25.

[10] Zahraa, H., A., A. Ghamdi (2008): Effects of commutative heat stress on immunoresponses in broiler chickens reared in closed system. Int J Poultry Sci, 7: 964-968. 


\section{Učinci dodatka vitamina C prehrrani na profil masnih kiselina u mesu prsa broj|era}

\section{Sažtak}

Cilj istraživanja bio je procijeniti koje učinke uvrštavanje tri različite razine vitamina C $(0,200$ i 400 $\mathrm{mg} / \mathrm{kg}$ ) u prehranu ima na profil masnih kiselina u mesu prsa brojlera. Istraživanje je provedeno u 3 ciklusa i 4 ponavljanja u trajanju od 42 dana, na potpuno randomiziranom uzorku od 10 pilića po kavezu, ukupno 120 jednodnevnih muških pilića komercijalnog hibrida Ross 308. Analiza podataka provedena je uporabom programa za statističku analizu SAS, dok je usporedba srednjih vrijednost izvršena Duncanovim testom višestrukog raspona uz vjerojatnost pogreške od $5 \%$. Rezultati su pokazali da se kod dodatka vitamina C razine $200 \mathrm{mg} / \mathrm{kg}$ smanjio postotak zasićenih masnih kiselina poput miristinske, palmitinske i stearinske kiseline, pri čemu se količina nezasićenih masnih kiselina povećala, a količina zasićenih masnih kiselina smanjila.

Ključne riječi: pilić, askorbinska kiselina, profil masnih kiselina

\section{Auswirkungen der Nahrungsergänzung mit Vitamin C auf das Fettsäureprofil in Broilerbrustfleisch}

\section{Zusammenfassung}

Ziel der Studie war es, die Auswirkungen der Aufnahme von drei verschiedenen Vitamin C-Mengen $(0,200$ und $400 \mathrm{mg} / \mathrm{kg})$ in die Ernährung auf das Fettsäureprofil im Broilerbrustfleisch zu bewerten. Die Studie wurde in 3 Zyklen und 4 Wiederholungen in Dauer von 42 Tagen durchgeführt, an einer vollständig randomisierten Probe von 10 Hühnern pro Käfig, insgesamt 120 männliche Hühner im Alter von einem Tag des kommerziellen Hybrids Ross 308. Die Datenanalyse wurde unter Verwendung des statistischen SAS-Analyseprogramms vorgenommen, während der Vergleich der Mittelwerte mit dem Duncan multiplen Vergleichstest mit einer Fehlerwahrscheinlichkeit von 5\% durchgeführt wurde. Die Ergebnisse zeigten, dass die Zugabe von Vitamin C in einer Menge von 200 $\mathrm{mg} / \mathrm{kg}$ den Prozentsatz an gesättigten Fettsäuren wie Myristinsäure, Palmitinsäure und Stearinsäure verringert, wobei die Menge an ungesättigten Fettsäuren zunahm und die Menge an gesättigten Fettsäuren abnahm.

Schlüsselwörter: Huhn, Ascorbinsäure, Fettsäureprofil

\section{Efectos de la suplementación dietétice de la vitamina C en el perfil de los ácidos grasos en la carne de broiler}

Resumen

El objetivo del estudio fue evaluar los efectos de la adición de tres niveles diferentes de la vitamina C (0, 200 y $400 \mathrm{mg} / \mathrm{kg}$ ) en la dieta, sobre el perfil de los ácidos grasos en la carne de broiler. El estudio fue realizado en 3 ciclos y 4 réplicas durante 42 días, con una muestra completamente al azar de 10 pollos por jaula, un total de 120 pollos machos de un día de edad del híbrido comercial Ross 308 . El análisis de los datos fue realizado utilizando el programa de análisis estadístico SAS, mientras que la comparación de los valores medios se realizó mediante la prueba de rango múltiple de Duncan con una probabilidad de error del 5\%. Los resultados mostraron que la adición de la vitamina C a un nivel de $200 \mathrm{mg} / \mathrm{kg}$ 
disminuyó el porcentaje de ácidos grasos saturados como el ácido mirístico, palmítico y esteárico, mientras que la cantidad de los ácidos grasos insaturados aumentó y la cantidad de los ácidos grasos saturados disminuyó.

Palabras claves: pollo, ácido ascórbico, perfil de los ácidos grasos

\section{Impatto dell'aggiunta della vitamina C sul profilo degli acidi grassi contenuti nella carne del petto dei polli da carne}

\section{Riassunto}

La ricerca è stata finalizzata alla valutazione dell'impatto dell'inserimento di tre differenti livelli di vitamina C (0, 200 e $400 \mathrm{mg} / \mathrm{kg})$ nel mangime sul profilo degli acidi grassi contenuti nella carne del petto dei polli da carne. La ricerca è stata svolta in 3 cicli e 3 ripetizioni, per la durata di 42 giorni, su un campione completamente randomizzato di 10 pulcini per gabbia, per un totale di 120 pulcini maschi di un giorno del tipo ibrido commerciale Ross 308. L'analisi dei dati è stata condotta con l'impiego del programma d'analisi statistica SAS, mentre la comparazione dei valori medi è stata eseguita con il test di comparazione multipla di Duncan con probabilità d'errore del 5\%. I risultati hanno dimostrato che, con l'aggiunta della vitamina C livello $200 \mathrm{mg} / \mathrm{kg}$, la percentuale di acidi grassi saturi come l'acido miristico, l'acido palmitico e l'acido stearico s'è ridotta, mentre è aumentata la quantità di acidi grassi insaturi ed è diminuita quella degli acidi grassi saturi.

Parole chiave: pulcino, acido ascorbico, profilo degli acidi grassi

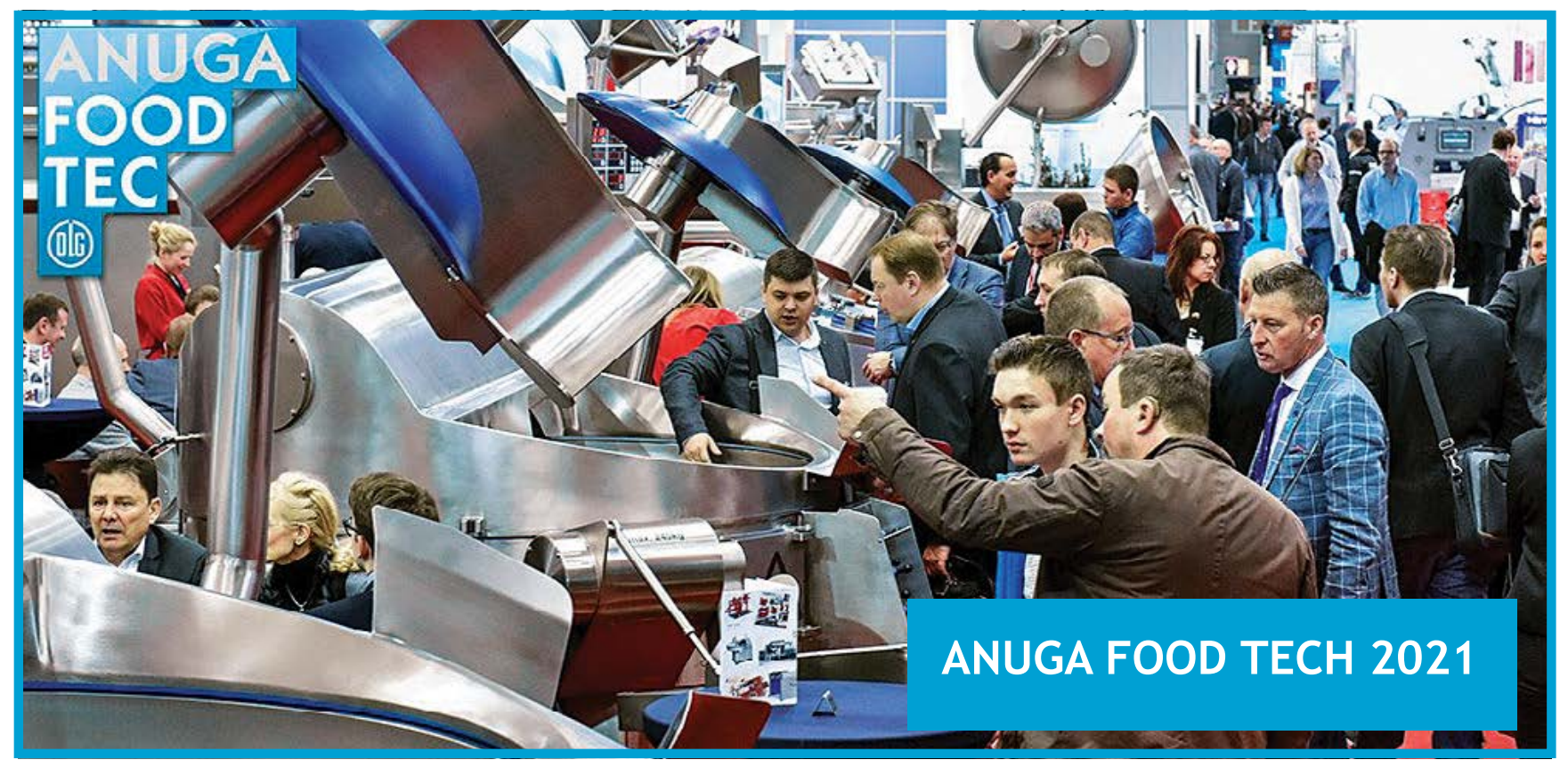

